\title{
The Impact of the German Tissue Act on the Manufactur- ing of Autologous and Allogeneic Stem Cell Preparations
}

\author{
Peter Schlenke Karin Tapernon Christoph Ahlke Alexandra Mertens Walter Sibrowski \\ Institut für Transfusionsmedizin und Transplantationsimmunologie, Universitätsklinikum Münster, Germany
}

\section{Key Words}

Stem cells · Bone marrow · Tissue Act - Transplantation .

Transfusion · Quality management system · Safety

\section{Summary}

Cellular therapeutic agents considerably contribute to the optimal treatment of patients with hematological malignancies such as leukemia or nonhematological disorders. Over the last 50 years especially the transplantation of autologous and allogeneic stem cells from different sources after high-dose or myeloablative chemotherapy became a wellestablished standard therapy that cures or alleviates the symptoms in more than 50,000 patients/year worldwide. In the near future, the current progress in fundamental research on stem cells and immunobiology will allow for the clinical implementation of novel advanced cellular therapies, including gene therapeutic options. The European and German legislation have realized the need of international regulations for improved standardization and harmonization of stem cell transplants, associated cell-therapeutic agents as well as various tissue-engineered preparations in the emerging field of regenerative medicine. The Tissue Directive 2004/23/EC, issued and ratified by the European Parliament in March 2004, and its national transition into the German Tissue Act which came into force in July 2007 define the quality and safety standards for the donation, procurement, testing, processing, preservation, storage, and distribution of human tissues and cells. These standards are of high relevance to ensure the efficient prevention of the transmission of viral and nonviral infectious pathogens and to achieve the same safeguards as in the population's blood supply. This review discusses the pros and cons of the new legislation and argues for keeping the administrative and regulative demands in reasonable limits and for offering innovative approaches of cellular therapies to the European citizens.

\author{
Schlüsselwörter \\ Stammzellen · Knochenmark · Gewebegesetz · \\ Transplantation · Transfusion · Qualitätsmanagement- \\ system $\cdot$ Sicherheit
}

\section{Zusammenfassung}

Zelltherapeutika tragen beträchtlich zur optimalen Behandlung von Patienten mit hämatologischen Erkrankungen wie z.B. Leukämien und nichthämatologischen Krankheitsbildern bei. In den letzten 50 Jahren wurde insbesondere die Transplantation autologer bzw. allogener Stammzellen zu einer gut etablierten Standardtherapie, die bei mehr als 50000 Patienten/Jahr zu einer Linderung oder Heilung ihrer Erkrankung führt. In naher Zukunft wird der gegenwärtige Fortschritt in der Grundlagenforschung der Stammzellen und Immunbiologie die klinische Einführung neuer fortschrittlicher Zelltherapien einschließlich gentherapeutischer Ansätze ermöglichen. Parallel hierzu hat die europäische und deutsche Gesetzgebung die Notwendigkeit von internationalen Vorschriften zur besseren Standardisierung und Harmonisierung von Stammzelltransplantaten, weiterführenden Zelltherapeutika als auch von zahlreichen Gewebezubereitungen im wachsenden Markt der Regenerativen Medizin erkannt. Die im März 2004 im Europäischen Parlament debattierte und verabschiedete Geweberichtlinie 2004/23/EG und deren nationale Überführung in das deutsche Gewebegesetz, welches im Juli 2007 in Kraft getreten ist, definieren die Qualitäts- und Sicherheitsstandards für die Spende, Beschaffung, Testung, Weiterverarbeitung, Konservierung, Lagerung und Verteilung von menschlichen Geweben und Zellen. Diese Standards sind von großer Bedeutung, um eine effiziente Vorbeugung der Übertragung von viralen und nichtviralen infektiösen Pathogenen zu gewährleisten und die gleichen Sicherheitsstandards wie bei der Versorgung der Bevölkerung mit Blutkomponenten zu erzielen. Dieser Übersichtsartikel diskutiert die Vor- und Nachteile der neuen Gesetzgebung und spricht sich dafür aus, die administrativen und regulativen Anforderungen in vernünftigen Grenzen zu halten und innovative Ansätze in der Zelltherapie der europäischen Bevölkerung anzubieten.

\begin{tabular}{ll}
\hline KARGER & $\odot$ 2008 S. Karger GmbH, Freiburg \\
Fax +497614520714 & Accessible online at: \\
$\begin{array}{l}\text { Information@Karger.de } \\
\text { www.karger.com }\end{array}$ & www.karger.com/tmh
\end{tabular}




\section{Introduction}

The law of the European Community is usually specified in directives such as Directive 2001/83/EC ('Medicinal Products for Human Use') [1] and Directive 2002/98/EC ('Blood Directive') [2] which are both well-known to institutions that produce blood components from voluntarily donated blood based on pharmaceutical standards (Good Manufacturing Practice (GMP)). In spring 2004, an additional directive, the Tissues and Cells Directive 2004/23/EC [3], was passed in the European Parliament. All member states of the European Community were obliged to transpose Directive 2004/23/EC into their national legislature within a period of 2 years. The mandatory implementation serves to provide a harmonization within all member states of the EU so that almost equivalent rights can be guaranteed for a comparable and risk-benefitbalanced access to novel therapies from the emerging field of regenerative medicine. For Germany, enactment started with the implementation of a special 'Tissue Act' which came into force in July 2007 [4]. This Tissue Act is not a law on its own, but leads to significant amendments of the Medicinal Products Act [5], the Transplantation Act [6], and the Transfusion Act [7]. These acts together with the German Drug Act (Arzneimittelgesetz (AMG); 12th and 14th amendments) and the German Ordinance for the Production of Medicinal Products and Active Substances (Arzneimittel- und Wirkstoffherstellungsverordnung; AMWHV) [8] represent the most important legal stipulations governing organs, blood components, tissues and cells (table 1). For more detail see von Auer $[9,10]$. As published by others [11], there are substantial differences between blood components, stem cell as well tissue transplants and synthetic pharmaceuticals so that the Council of Europe made arrangements to separate clearly the legal framework for blood components from that for classical pharmaceuticals. In this view the German Tissue Act might contradict the political claim to keep the legal complexity in reasonable limits.

\section{General Implications of the German Tissue Act for Tissue and Cell Preparations}

The Directive 2004/23/EC (published in November, 2007, come into force in December, 2008) [3] includes minimum standards that are designed to ensure high quality and safety margins for human tissues and cell preparations released for clinical application in humans. The demands for standardization cover the donation, procurement, testing, processing, preservation, storage, and distribution of human tissues and cells (table 2).

The German Tissue Act exceeds these minimum requirements and is designed to aspire to the highest level of quality for supplying the German population with safe tissue and cell preparations while, at the same time, keeping restrictions in mind re-
Table 1. The legal framework for organs, blood, tissues and cells

European legal framework
EC-GMP Guidelines (1989)
Directive 2001/83/EC
Directive 2002/98/EC
Directive 2004/23/EC
EC treaty for Advanced Therapy Medicinal Product Regulation
(1394/2007/EC)

German legal framework

Drug Act (AMG since 1976)

Medicinal Products Act (MPG since 1994)

Transplantation Act (TPG since 1997)

Transfusion Act (TFG since 1998)

Tissue Act (Gewebegesetz since 2007)

Table 2. Issues of Directive 2004/23/EC and of the German Tissue Act

Surveillance of the manufacturing of tissue preparations by authorities Surveillance of the manufacturing of stem cell preparations by authorities Establishment of licensed tissue and cell banks

Regular inspections of licensed tissue and cell banks (every 2 years)

Period of time to keep relevant documents for look-back procedures

(30 years)

Regulation of import and export conditions for tissue preparations

Establishment of a national register (annual report system)

Criteria for donor selection

Introduction of a quality management system

Nomination of a responsible person for tissue banks (2 years experience)

Requirements for procurement, manufacturing, packaging and distribution

Table 3. Major categories of different tissues (approval required)

Musculoskeletal tissues (bone, muscle, tendon, soft tissue)

Cornea and sklera

Epidermis

Cardiovascular tissues (vessel, heart valve, pericardial tissue)

Others (amnion, placenta, embryonic/fetal tissue)

garding the safety of blood supplies that first came to light when the HIV crisis was in full flow during the early 1990s. Despite the critique of the German Medical Association (Bundesärztekammer) and various medical societies and despite of other statements [12], the final German Tissue Act still defines tissues and cell preparations as pharmaceutical drugs governed by the German Drug Act. Amendments to this act (e.g. Section 4a) highlight the need for high standards in quality and safety and close most of the loopholes that might otherwise allow operation outside national drug legislation in the field of local tissue banking and tissue engineering $[13,14]$. The German Tissue Law seems to be heading in the direction that donated tissues, including stem cell preparations, must be subject to the same strict regulations as pharmaceutical products, preventing the most serious adverse effects of allogeneic tissue transplants, that is the transmission of 
Fig. 1. Illustration of the current legal framework to produce and release blood components, stem cell preparations, and tissues.

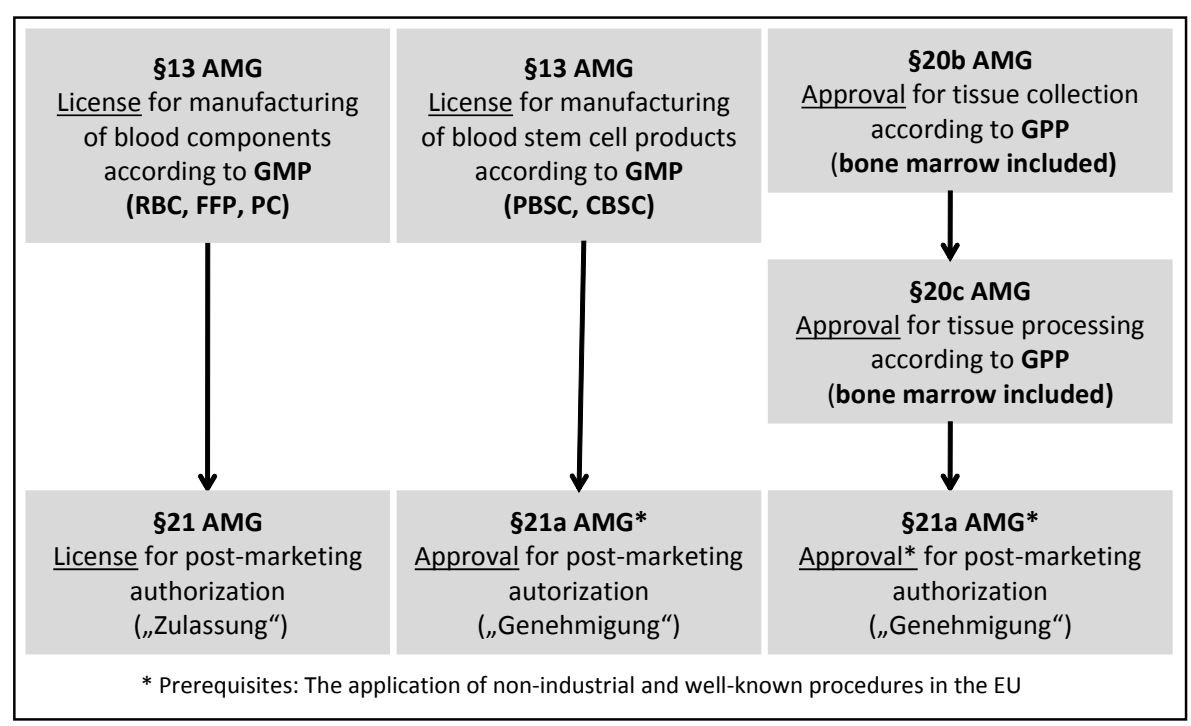

viral and nonviral infectious pathogens. Whenever possible, a validated inactivation procedure should included in the manufacturing process $[15,16]$.

The term 'tissue' for medicinal purposes includes all tissue components from a human body that are not defined as organs ('functionally intact unit') as listed in table 3, which also includes single cells. Human bone marrow, fetal cells/tissues and germ cells (oocytes and sperms) are all listed as 'tissues'. Whole blood, blood components, and consequently stem cells derived from peripheral blood or cord blood are excluded from this definition. Other specialized cells such as immunocompetent cells derived from peripheral blood are also covered by this exclusion criterion. It seems appropriate to alert potential applicants for novel therapeutic agents that another EU treaty for Advanced Therapy Medicinal Product Regulation (1394/2007/EC) [17] shall be coming up in December 2008 , and that this shall contain deadlines for commercially distributed medicinal products in the fields of gene therapy, somatic cell therapy and tissue engineering. Deadlines for the transition into marketing authorization are as follows:

- for gene therapy medicinal products December 2012

- for somatic cell therapy medicinal products December 2012 - for tissue engineered medicinal products December 2013.

The term 'tissue preparation' refers to unmanipulated tissues per se as well as any novel preparations whose preparation is based on such primary tissues. Such tissue preparations are pharmaceuticals according to section 4 (30) of the German Drug Act. However, there are two major exceptions: i) germ cells such as oocytes (fertilized or nonfertilized) or, spermatozoa and ii) embryos in toto.

Now that the German Tissue Act has come into force, such tissues, currently defined as pharmaceuticals, usually require national approval (so-called 'Genehmigungsverfahren') which in principle is comparable, although somewhat simplified, to the well-established national licensing procedure for blood components seeking postmarketing approval from the national au- thorities (Paul Ehrlich Institute) (so-called 'Zulassungsverfahren') (fig. 1). The extent to which national approvals for tissue preparations have contributed to a significantly improved quality and essentially higher safety profile for each treated patient and the extent to which these efforts are well-balanced in the light of the well-known overregulation and bureaucracy at both the national and European levels is still a matter of some dispute. Emerging therapeutic options using tissue-engineered grafts have required timely national requirements to ensure a high quality of treatment and approximately equivalent safeguards for all citizens of the European Union, especially in preventing the transmission of tissue- or transplant-associated infectious pathogens. Keeping this spirit in mind, the German Tissue Act in fact represent a systematic continuation of the tradition of national legislation that has prevailed over past decades. Not surprisingly, legal regulation of tissue and cell preparations now considers the highly positive experiences obtained with the standardization and licensing of blood components for ensuring the highest quality and optimal implementation of a local and national system for surveillance.

Under certain circumstances the above-mentioned permissions are not required, e.g. if the tissue preparation is manufactured for an individual patient under the direct professional responsibility of the same physician who applies this tissue preparation, or if the tissue is immediately taken from the patient and retransferred within the same treatment cycle. Examples for such tissue preparations are autologous transplants which are transposed within a (surgical) treatment e.g. cranium, pancreatic insulin-producing beta-cells, and parathyroids. The application procedure for tissues using the standards of Common Technical Documents (CTD module 1-5), the review process, and the final decision-making by the national authorities is summarized in another article of this special issue of Transfusion Medicine And Hemotherapy [18]. In addition, an overview of CTD modules applicable to any kind of stem cell preparations is given in figure 2 . 


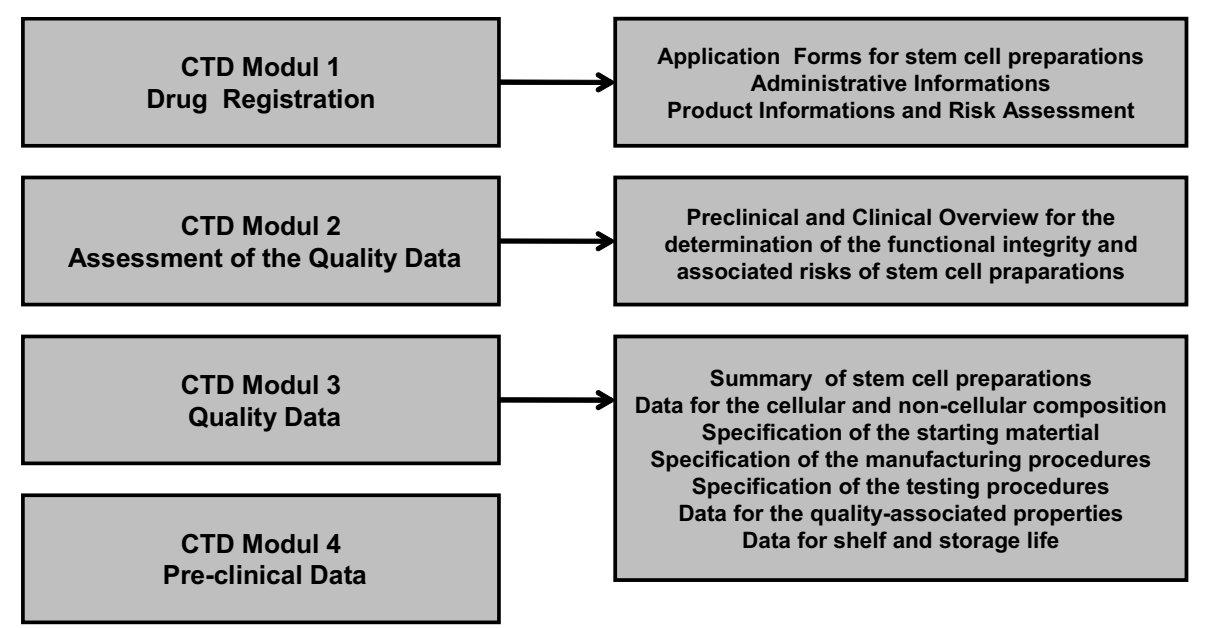

Fig. 2. Structure of the Common Technical Documents (CTD) adapted to the requirements of stem cell preparations.

\section{CTD Modul 5}

Clinical Data

\section{Specific Implications of the German Tissue Act for Hematopoietic Stem Cell Preparations}

As illustrated above, all hematopoietic stem cell preparations listed in table 4, whether they are derived from peripheral blood and cord blood (per definition blood components) or from bone marrow aspirates (per definition tissues), require national approval by the Paul Ehrlich Institute, irrespective of the patients' transplantation strategy (autologous versus allogeneic). The only exception is the manufacturing of allogeneic cord blood units that are collected in advance so that these products can be transplanted later to a as yet (at the date of donation) unknown recipient. Such cord blood preparations, like allogeneic blood components, require a standard national licensing procedure governed by the German Drug Act. Other sources of hematopoietic stem cells, such as cells from fetal liver or embryonic stem cells, are not considered any further because especially in Germany they are unlikely to become a realistic clinical option in the near future for ethical and legal reasons.

For such applications, all further steps in the production process must be carefully indicated. This implies both a minimization of the manipulative steps, such as volume reduction and cryopreservation, and additional production procedures that have a significant impact on the ultimate product properties, such as the enrichment of target cells or the depletion of undesirable contaminants. A representative selection of such procedures is given in table 5 .

As a consequence of the German Tissue Act that came into force in July 2007, all institutions treating patients with hematopoietic stem cell preparations (mainly departments of transfusion medicine or centers for stem cell transplantations) submitted applications to the Paul Ehrlich Institute within the published deadline (February 1, 2008). Up until the time of
Table 4. Sources for hematopoietic stem cell preparation

\begin{tabular}{ll}
\hline $\begin{array}{l}\text { Peripheral blood } \\
\text { Autologous setting }\end{array}$ & \$21a approval \\
Allogeneic setting & \$21a approval \\
Bone marrow & \\
$\quad$ Autologous setting & \$21a approval \\
Allogeneic setting & \$21a approval \\
Cord blood & \\
$\quad$ Autologus setting & \$21a approval \\
Allogeneic setting & \$21 licensing \\
Fetal liver & not yet clinical approved \\
\hline
\end{tabular}

Table 5. Additional manufacturing steps of stem cell preparations

Total volume or plasma and platelet reduction

Enrichment of mononuclear cells, depletion of erythrocyte contamination Enrichment of stem cells (CD34+ or CD133+)

Depletion of T and B lymphocytes (CD3+ CD19+)

Cryopreservation

writing, the German Society for Transfusion Medicine and Immunohematology (DGTI) has been editing a 'draft version' of a supplementary statement in close agreement with the German Society for Hematology and Oncology (DGHO) and the Society for Pediatric Oncology and Hematology (GPOH) as an extension to these applications. It summarizes the required preclinical and clinical data (CTD modules 2.4 and 2.5) for assessing the functional integrity of the respective stem cell preparation and their risk-benefit profile. This overview contents experimental data from animal studies to the pharmacokinetic and pharmacodynamic properties of hematopoietic stem cells which try to explain both the mechanisms of stem 
cell mobilization into the circulation and the their homing within the bone marrow niche. The final version of this statement shall include a detailed assessment of the pharmacokinetic and toxicological profile of dimethylsulfoxide (DMSO) written by two experts in this field. DMSO is the most relevant additive in all cyropreserved stem cell preparations and serves as cyroprotectant for most types of nucleated cells. The review processes for the CTDs and co-submitted documents being undertaken by national authorities are still ongoing, and decisions are not expected before the turn of the year.

At this point it should be stated that legislators have now succeeded in closing a longstanding loophole in the specification of hematopoietic stem cell transplantation products. Institutions which exclusively manufacture stem cell products may no longer benefit from the favorable circumstances of the past and might unwillingly accept that they are now confronted with a huge administrative burden that now includes declarations of product specifications, provision of efficacy and safety data, and the submission of standard operating procedures, common technical documents and other relevant documents (standards for look-back procedures, systems for pharmacovigilance and risk management). Tissue banks and stem cell transplantation centers are well advised to focus on comprehensive and robust quality assurance in all areas of donating, testing, procurement and preservation. The professional handling of all such matters is traditionally well-established in pharmaceutical companies which release their cellular blood components and coagulation products on the basis of company-related licenses that ensure high-level quality standards and safety margins. Thus, knowledge of the legal framework and correctness in dealing with local and national authorities are both good prerequisites for blood centers, whether it be for meeting new demands or for offering themselves as competent cooperation partners.

Nevertheless, legislators and national authorities should carefully balance the practicality of regulations that have just come into effect through the German Tissue Act. The efforts and expenses to meet these new requirements have to keep in reasonable limits. The transplantation of hematopoietic stem cells has for some time been a globally accepted treatment option for patients with malignancies and other congenital disorders such as primary immune disorders. As highlighted by Frederick Appelbaum [19], 2007 marked the 50th anniversary of the initial report by Thomas et al. [20] on the intravenous infusion of bone marrow after a radio-/chemotherapy. Since that time, and after overcoming severe clinical restrictions in the 1960s and 1970s, more than 50,000 people per year have now undergone hematopoietic stem cell transplantations of which almost 20,000 are allogeneic transplantations using related or unrelated donors. Until now more than 11 million HLA-typed donors and cord bloods are available in national registries such as the Bone Marrow Donor Worldwide Registry. For European patients, in approximately three of four cases an acceptable HLA-matched donor could be identified with more than $50 \%$ probability of a $10 / 10$ match, which means that the patient and donor share the same five alleles on both haplotypes (HLA-A,-B-C, DRB1 and DQB1) [21].

Based on these facts and the urgent need for autologous and allogeneic stem cell transplantations for life-threatening diseases, neither the harmonization of the European Law nor the accentuation of national legal requirements should seriously endanger patients' lives or their right to receive an optimal treatment in time. Therefore, the introduction of a mandatory demand for approvals to manufacture hematopoietic stem cell products for transplant purposes should lead neither to a bottleneck nor a lengthening of waiting lists for potential transplant candidates. In addition, most, if not all, of the national centers involved in stem cell transplantations are registered and certified by local authorities and international accreditation societies that ensure the application of GMP standards and the use of an appropriate quality management system within the respective institutions. Keeping this in mind, all responsible individuals should make the boldest attempts to prevent the spirit of the German Tissue Act being lost in red tape, and the patients' interests being ride roughshod over.

Furthermore, all participants will continue to learn that stem cell transplantations represent only one component of a patient's individualized treatment schedule. A broad variety of stem cell preparations now exist for optimizing a patient's fight against cancer, improving disease-free survival and increasing the overall quality of life. Stem cells preparations are not comparable to blood components such as red blood cell units which are collected and produced in millions of units per annum using 'universal' manufacturing standards and standardized final product specifications. The national authorities in Germany have recognized the specific properties of stem cell preparations and their individual production on a patientto-patient basis. This is especially true for unrelated allogeneic transplantations in which the best HLA-matched donor has to be identified to prevent graft-versus-host disease and graft failure. The tissue compatibility is determined by a set of high polymorphic genes of the HLA complex. Nowadays molecular DNA typing methods using PCR technology and DNA sequencing allow for HLA typing on a high-resolution level resulting in an improved selection of unrelated donors which contributes to a better clinical outcome [21].

Consistently with this patient-related perspective, the Paul Ehrlich Institute now demands a declaration of quality-associated properties of stem cell preparations rather than any final and preset product specifications. These quality-related properties are summarized in table 6. By applying this modus operandi, the Paul Ehrlich Institute addresses the idiosyncrasies of stem cell preparations that require discretion to be exercised.

The optimal endpoint for assuring the quality of a transplanted product is the complete engraftment of hematopoiesis to a patient. From this viewpoint, both the duration of aplasia until recovery of leukocyte and platelet numbers (>500 neu- 
Table 6. Quality-associated properties of stem cell preparations

Determination of $\mathrm{ABO}, \mathrm{Rh}-(\mathrm{D})$ and status of antibody screening Negative testing for HBs antigen, anti-HBc antibody and HBV-NAT

Negative testing for anti-HCV and HCV-NAT

Negative testing for anti-HIN1/2 antibody and HIV1-NAT

Negative testing for anti-Treponema pallidum antibody

Determination of the anti-CMV status (IgM and IG)

(If necessary, anti-HTLV-I/-II, CMV-NAT, parvovirus B19)

Declaration of the product volume

Declaration of total nuclear cells and/or CD34+ cells (and their viability)

Declaration of colony-forming potential (CFU-GM)

Declaration of RBC contamination

Negative result of sterility testing or, if necessary antibiogram

Visual check

trophils/ $\mu$ l and $>20$ platelets/nl) and the timeframe over which independence from exogenous blood supplies (red blood cell units and platelet concentrates) is achieved are of high relevance for objectively assessing the hematopoietic reconstitution in vivo. The quality-associated properties mentioned above are in vitro parameters that might serve as adequate surrogate markers for assessing this engraftment potential. Indeed, the accurate determination of the CD34+ stem cell dose represents the most important analysis since it directly correlates with hematological engraftment. Nowadays, the singleplatform flow-cytometric analysis of CD34+ cell counts based on fluorescent microbeads is a well established procedure for enumerating stem cells in accordance with internationally accepted ISHAGE standards [22]. This platform allows for the simultaneous measurement of cell viability using the nuclear stain 7-AAD which specifically intercalates into the DNA of dead cells that are unable to contribute to the desired hematopoietic engraftment. Thus, the identification and quantification of 7-AAD+ events should be directly related to the total number of nucleated cells (approximately all leukocytes) or, more preferably, the subpopulation of CD34+ target cells. Ultimately, the concentration of viable CD34+ stem cells in the thawed transplant products (or thawed aliquots of representative samples) might be a suitable in vitro parameter that correlates with in vivo engraftment and may also be sufficient for predicting the outcome of a hematopoietic reconstitution. Nevertheless, the all pre-analytical steps involving thawed, DMSO containing samples, such as washing or dilution, and the subsequent flow-cytometric stem cell quantification using anti-CD34 antibodies have to be standardized and validated, especially for the purposes of ensuring that cyropreserved and subsequently thawed stem cells express stable CD34 antigens on the cell surface that is not masked for unknown reasons on freshly thawed cells.

Apart from the above discussed flow-cytometric approaches, short-term culture assays are also widely used for estimating the proliferation capacity of myeloid and erythroid progenitor cells [23]. Under optimized growth and differentiation conditions, such progenitors are usually able to generate in vitro lineage-specific colonies such as CFU-GM and BFU-E/CFU-E. In the meantime, growth of CFU-GM per se serves as a useful parameter for revealing that at least a proportion of the viable CD34+ cells collected for transplantation purposes are cell-cycle active progenitors that divide into daughter cells and are able to contribute to the clonal expansion of mature cells. These progenitor cells are lineage-restrictive rather than immature and pluripotent stem cells. As such it is doubtful whether colony-forming cells are able to function as surrogates for true pluripotent stem cells, or indeed as indicators for hematopoietic reconstitution over the long term. In this context, any attempt to quantify CFU-GM content in transplant products is restricted by the huge variety of growth factor-containing media supplements and the resulting poor standardization of such cell culture systems, including also microscopic evaluation. Historically, it is well known that the CFUGM content correlates with short-term hematopoietic engraftment even though the current standard of CD34+ cell concentration/kg body weight is more precise. Furthermore, approximately 10-20\% of CD34+ cells that build up CFU-GM colonies depend on the culture medium used as well as how and how many CD34+ cells are seeded onto the culture dishes. As a result, the use of time-consuming short-term culture assays and its sophisticated microscopic evaluation as an addition to the flow-cytometric quantification of CD34+ cells does not provide a more proper assessment of the quality and safety of stem cell products. A mandatory and regular usage of short-term culture assays to indicate quality therefore cannot be generally recommended.

\section{Closing Remarks}

Taking these findings together, the selection of applicable in vitro parameters and underlying methodologies are of prime importance for improving the quality and safety of stem cell preparations as regards their unique potential to reconstitute both the hematopoietic and immune systems in their entirety after transplantation. Blood centers, pharmaceutical companies, and national authorities must focus their attention on the accurate validation of methods used for the manufacturing, testing, and characterization of the essential quality-related properties of stem cell preparations. Combined with all other requirements that shall become mandatory following the enactment of European Directive 2004/23/EC and the German Tissue Act, these efforts will be of great value for standardizing and improving quality and safety of the manufacture of autologous and allogeneic stem cell transplantations in order to a achieve a standard as high as that already guaranteeing the population's blood supply for years. 


\section{References}

1 Directive 2001/83/EC of the European Parliamen and the Council of 6 November 2001 on the Com munity Code relating to Medicinal Products fur Human Use. Official Journal of the European Union L311 pp 67-128, 28.11.2001.

2 Directive 2002/98/EC of the European Parliament and the Council of 27 January 2003 setting standards of quality and safety for the collection, testing, processing, storage and distribution of human blood and blood components and amending Directive 2001/83/EC. Official Journal of the European Union L33 pp 30-40, 08.02.2003,

3 Directive 2004/23/EC of the European Parliament and the Council of 31 March 2004 on setting standards of quality and safety for the donation, procurement, testing, processing, preservation, storage and distribution of human tissues and cells. Officia Journal of the European Union L102 pp 48-58, 07.04.2004.

4 Gewebegesetz (GewebeG) vom 20.07.2007 (BGBl. I S.1574).

5 Arzneimittelgesetz (AMG) in der Fassung der Bekanntmachung vom 12.12.2005 (BGBl. I S.3394, zuletzt geändert durch Artikel 9 Abs. 1 des Gesetzes vom 23.11.2007 (BGBl. IS.2631).

6 Transplantationsgesetz (TPG) in der Fassung der Bekanntmachung vom 04.09.2007 (BGBl. I S.2206)

7 Transfusionsgesetz (TFG) in der Fassung der Bekanntmachung vom 28.08.2007 (BGBl. I S.2169).

8 Arzneimittel- und Wirkstoffherstellungsverordnung (AMWHV) vom 03.11.2006 (BGBl. I S.2523, geändert durch den Artikel 1 des Gesetzes vom 26.03.2008 (BGBl. I S.521).

9 Von Auer F: Das Gewebegesetz - Hintergründe und Konsequenzen. Transfus Med Hemother 2008; 35(6):431-437.
10 Von Auer F: Die Umsetzung europäischer Richtlinien in innerstaatliches Recht am Beispiel der Geweberichtlinie 2004/23/EG. BGBl 2008;51:757-763.

11 Müller T, Pohl U: Arzneimittel- und Wirkstoffherstellungsverordnung (AMWHV): Wieviel Arzneimittelrecht braucht die Transfusionsmedizin noch? Transfus Med Hemother 2007;34:138-142.

12 Middeler G, Machens H-G: Kommentar zur Arbeit von A. Pruß und R. von Versen: Einfluss europäischer Regulativa auf Qualität, Sicherheit und Verfügbarkeit allogener Zell- und Gewebetransplantate in Deutschland. Handchir Mikrochir Plast Chir 2007:39:88-90.

13 Verordnung über die Anforderungen an Qualitä und Sicherheit der Entnahme von Geweben und deren Übertragung nach dem Transplantationsgesetz (TPG-GewV). Vom 26.03.2008 (BGGl. I S. 512).

14 Verordnung für ein Register über Einrichtungen, die Blutstammzellzubereitungen herstellen, in den Verkehr bringen oder einführen (Blutstammzelleinrichtungen-Registerverordnung (BERV) vom 20.12.2007 (BGBl. I S.3081)

15 Pruss A, von Versen R: Einfluss europäischer Regulative auf Qualität, Sicherheit und Verfügbarkeit allogener Zell- und Gewebetransplantate in Deutschland. Handchir Mikrochir Plast Chir 2007; 39:81-87.

16 Pruss A, Katthagen B-D: Muskuloskelettale Gewebebanken. Rechtliche Grundlagen und Transplantatsicherheit. Orthopäde 2008;37:749-755.
17 Regulation (EC) No 1394/2007 of the European Parliament and of the Council of 13 November 2007 on advanced therapy medicinal products and amending Directive 2001/83/EC and Regulation (EC) No 726/2004. Official Journal of the European Union L324 Page 121-137, 10.12.2007.

18 Schilling-Leiß D, Godehardt AW, Scherer J, Cichutek K, Tönjes RR: Genehmigungsverfahren für klassische Gewebezubereitungen gemäß § 21a Arzneimittelgesetz (AMG). Transfus Med Hemother 2008;35(6):453-462.

19 Appelbaum F: Hematopoietic-cell transplantation

at 50. N Engl J Med 2007;357:1472-1475.

20 Thomas ED, Lochte HL, Lu WC, Ferrebee JW: Intravenous infusion of bone marrow in patients receiving radiation and chemotherapy. $\mathrm{N}$ Engl J Med 1957;257:491-496.

21 Tiercy JM: The role of HLA in HSCT; in Apperley J, Carresras E, Gluckman E, Gratwohl A, Maszi T (eds): The ESH-EBMT Handbook on Haematopoietic Stem Cell Transplantation, chapter $3 \mathrm{Im}$ munogenetics of Allogeneic HSCT. Paris, ESH, 2008.

22 Keeney M, Chin-Yee I, Weir K, Popma J, Nayar R, Sutherland DR: Single platform flow cytometric absolute counts based on the ISHAGE guidelines. $\mathrm{Cy}$ tometry 1998;34:61-70.

23 Sheikhzadeh S, Hammers HJ, Hartwig D, Kirchner $\mathrm{H}$, Schlenke P: Improvement of the precision in CFU-GM and BFU-E counting by flow cytometrybased standardization of short-term culture assays. J Hematother Stem Cell Res 2001;10:881-885. 